\title{
The importance of owner-managed SMEs and regional apprenticeship activity: evidence from the German Mittelstand
}

Vera Jahn ${ }^{*}$ (D)

\author{
*Correspondence: \\ vera.jahn@hsu-hh.de \\ Helmut Schmidt University \\ Hamburg, Holstenhofweg 85, \\ 22043 Hamburg, Germany
}

\begin{abstract}
Background: Politicians frequently emphasize the importance of Mittelstand firms for the economy, thereby particularly referring to their enormous engagement in training apprentices. This view is especially prevailing in Germany, leading to political promotion of Mittelstand firms on the regional and the national level. However, due to data availability, there is yet almost no empirical evidence on the question whether Mittelstand firms are in fact excessively active in training apprentices. This paper aims at filling this gap in the empirical literature by using a firm dataset from Creditreform.

Methods: Combining information from Creditreform with regional data of West German counties, we study whether the relative importance of owner-managed small and medium sized enterprises has an effect on firms' apprenticeship activity.

Results and Conclusions: We thereby find a significantly positive relation between the relative importance of Mittelstand firms and apprenticeship activity on the regional level. However, on the national level an increase in the share of Mittelstand firms turns out to be without effect on apprenticeship activity.
\end{abstract}

Keywords: Apprenticeship, Mittelstand firms, Owner-management, SMEs, Regional spillovers, Germany

JEL Classification: C21, D23, 121

\section{Introduction}

In many countries owner-managed small and medium sized enterprises (SMEs) are seen as superior form of organizing business. This view is particularly prevailing in Germany, where this kind of enterprise is referred to as Mittelstand. ${ }^{1}$ German politicians frequently stress the importance of owner-managed SMEs for the German economy by arguing 'the German Mittelstand is the engine of the German economy' and 'the Mittelstand is Germany's economic backbone' (Federal Ministry of Economics and Technology 2013; Federal Chancellor Angela Merkel 2009; Ministry of Economic Affairs 2014).

\footnotetext{
${ }^{1}$ Besides owner-management and a small firm size, further characteristics of Mittelstand firms are discussed in the literature. Mittelstand firms are said to be long-term oriented, well embedded in the region they are located in, and have long-lasting relationships to suppliers, clients, and employees. Moreover, they are often characterized as export oriented and highly flexible due to flat hierarchies (Audretsch and Lehmann 2016). However, since these characteristics are not measureable on the regional level, the following empirical analysis concentrate on owner-management and a small firm size only.
}

(c) The Author(s) 2018. This article is distributed under the terms of the Creative Commons Attribution 4.0 International License (http://creativecommons.org/licenses/by/4.0/), which permits unrestricted use, distribution, and reproduction in any medium, provided you give appropriate credit to the original author(s) and the source, provide a link to the Creative Commons license, and indicate if changes were made.

\section{Springer Open}


As a consequence of the deeply rooted belief in the important role of Mittelstand firms, German politics has launched various political programs promoting the German Mittelstand on the regional and the national level (see e.g. Bavarian Ministry of Economic Affairs and Media, Energy and Technology (2009), Federal Ministry of Economic Affairs and Energy (2014)). ${ }^{2}$ Due to the well performing German economy, there has recently been an increasing international attention in German owner-managed SMEs (see e.g. UK Trade and Invest et al. (2014)). Many countries are interested in the German Mittelstand model and some even aim at emulating it (see e.g. Kirchfeld and Randow (2010), Blackstone and Fuhrmans (2011), Fear (2014)). It is argued that Mittelstand firms essentially contribute to the resilience of the German economy in economic crises (Girotra and Netessine 2013; Berghoff 2006). The German Mittelstand is also said to account for a large share of total economic output and employment and to be overly innovative (Federal Ministry of Economics and Technology 2013).

German politics also often claims Mittelstand firms to make a major contribution to the German apprenticeship system by employing a large proportion of apprentices (Federal Ministry of Economics and Technology 2013; Ministry of Economic Affairs 2014). Since apprenticeship training helps to meet firms' demand for skilled labour, it is economically highly relevant (Federal Ministry of Economics and Technology 2014) and essential in the light of the prevailing demographic trends. Furthermore, apprenticeship training might contribute to minimize youth unemployment (Winkelmann 1996; Shackleton 1997) and thus reduces social spending for the unemployed (Franz et al. 2000).

The existing literature provides various theoretical explanations why Mittelstand firms might be highly engaged in training apprentices. The employed arguments are typically based on the assumption that firms train apprentices in order to retain productive apprentices as skilled employees after graduation. Thus, firms' training efforts are seen as an investment in future skilled human capital, a view which is referred to as investment motive (Becker 1993; Acemoglu and Pischke 1999). In this context, firms might use apprenticeships to gain information about potential future employees in order to minimize the risk of retaining unproductive workers (Franz et al. 2000; Krämer 2003; Wagner 1998). Additionally, few theoretical explanations are based on the idea that firms provide apprenticeships in order to extract rents from the apprentices paying wages below productivity, referred to as production motive. Besides learning a trade, apprentices might take over tasks in the production process of a firm usually done by semi-skilled or skilled workers, without being paid respective wages (Ryan 2001; Busemeyer et al. 2012; Backes-Gellner and Mohrenweiser 2010).

The existing literature discusses the two dimensions of Mittelstand firms (owner-management, SMEs) separately. The first strand of the literature explains why owner-managed firms might be highly active in training apprentices. In owner-managed firms owners make strategic decisions at their own risk. If these decisions e.g. concerning human resources are wrong, they have to bear the resulting costs themselves. Therefore, especially owner-managed firms might use apprenticeships to gather information about potential employees in order to minimize the risk of employing unproductive workers.

2 Political programs e.g. give credits with favourable conditions to Mittelstand firms or subsidize their research and development facilities (Federal Ministry of Economic Affairs and Energy 2015). 
Moreover, owner-managed firms usually are long-term oriented (Institut für Mittelstandsforschung Bonn 2013), which likely increases the incentive to train apprentices. The second strand of the literature argues why SMEs might engage excessively in the apprenticeship system. Due to the attractiveness of large employers ${ }^{3}$, trainees might complete their apprenticeships in small firms and then switch to other employers afterwards, thereby counteracting the investment motive of the training firms (Hamel 2006; Krämer 2003). Therefore, SMEs may train a relatively large number of apprentices in order to compensate quitting graduates. Additionally, SMEs often have flat hierarchies that might simplify collecting information about potential employees during apprenticeships. Furthermore, particularly small firms active in craft industries might train a relatively large number of apprentices according to the production motive since apprentices' contribution to the production process tends to be relatively high in these firms (Busemeyer et al. 2012; Franz et al. 2000; Winkelmann 1996). According to Fama and Jensen (1983), owner-management especially makes sense in small noncomplex firms. Therefore, one might in fact expect owner-managed SMEs to train a relatively large number of apprentices, as politicians often claim.

However, there is yet almost no empirical evidence on the question whether ownermanaged SMEs are in fact overly engaged in the German apprenticeship system. This is likely due to the fact that official statistics often do not report on the owner and governance structure of enterprises and thus impede the identification of owner-managed firms. Even employer surveys like the IAB Establishment Panel, providing detailed information on employment at the establishment level, do not allow identifying owner-managed enterprises. This is due to the fact that the IAB Establishment Panel does not distinguish between owner-managed enterprises and family firms. However, while many family firms are owner-managed, this does not hold true for all family firms. In family firms sometimes one part of the family owns at least parts of the enterprise whereas other family members manage the firm. Thus, ownership and management are not necessarily conjoint in the same person. ${ }^{4}$

This paper aims at filling the gap in the empirical literature by using a dataset that allows us to identify owner-managed SMEs on a detailed regional level. Thus, we analyze the relationship between the relative importance of owner-managed SMEs and firms' apprenticeship activity on the county level. ${ }^{5}$ The relative importance of owner-managed SMEs is measured by the share of Mittelstand firms in all economically active firms in a region. In order to measure firms' apprenticeship activity, we use the share of apprentices in all employees subject to social insurance contributions on the regional level. ${ }^{6}$ Since firms' apprenticeship activity might not only depend on local characteristics, e.g.

\footnotetext{
${ }^{3}$ Wagner (1997) finds large companies to pay higher wages and fringe benefits than small firms in Germany. Moreover, employees' opportunities for skill enhancement turn out to increase with firm size.

4 Specifics of family firms compared to owner-managed firms are discussed e.g. in Chrisman et al. (2004), Kets de Vries (1993) and Chu (2009).

5 German counties correspond to the European NUTS-3-level.

${ }^{6}$ Related empirical studies often differentiate between firms' propensity to train apprentices and firms' training intensity, given they decided to train apprentices in general. Since we are interested in the total effect of the relative regional importance of Mittelstand firms on firms' apprenticeship activity, there is no need to distinguish. We instead focus on the share of apprentices in all employees in all enterprises, training and non-training firms. Moreover, the empirical literature finds a significantly positive effect of firm size on firms' propensity to train apprentices (see e.g. Beckmann (2002), Mühlemann et al. (2007)). Thus, if we find a significantly positive impact of the relative regional importance of owner-managed SMEs on firms' apprenticeship activity, we expect this effect even to be underestimated.
} 
the situation on the domestic labour market or the local supply of potential trainees, but also on characteristics of surrounding regions, we estimate spatial models in order to take spatial dependencies between regions into account. Controlling for various types of spatial dependencies, we detect a significantly positive effect of the relative importance of owner-managed SMEs on firms' apprenticeship activity on the county level. Thus, regions with a higher relative importance of Mittelstand firms might attract potential trainees from other regions and thus train a larger number of apprentices relative to all employees. However, regional competition for potential trainees leads the regional advantage of a higher relative importance of Mittelstand firms to disappear when other regions show a higher relative importance of owner-managed SMEs as well. Thus, we do not find a significant effect of the relative importance of owner-managed SMEs on firms' engagement in the apprenticeship system on the national level. Therefore, our empirical results lead to different policy implications on the regional and on the national level.

The remainder of this paper is organized as follows. The second section delivers an overview of the German apprenticeship system. Section three outlines the estimation approach and introduces the employed datasets. Sections "Results and discussion" and "Limitations" present the empirical results. The final section summarizes the main results and draws some conclusions.

\section{Institutional background}

The German system of apprenticeship training is often recognized as exemplary compared to the training systems of other developed countries (Beckmann 2002) as it provides theoretical and practical knowledge of high quality (Federal Ministry of Economics and Technology 2009). German apprenticeship training takes place in public vocational schools, teaching theoretical knowledge, and private firms, training apprentices in practical skills. Therefore, the German system is also referred to as dual vocational training system (Zimmermann et al. 2013; Troltsch and Walden 2011). Creating graduates with theoretical and practical knowledge, the German apprenticeship system helps to meet the firms' demand for skilled labour, necessary to produce product and services of high quality (Federal Ministry of Economics and Technology 2009, 2014). Thereby, the apprenticeship system might contribute to a relatively low youth unemployment rate in Germany (Winkelmann 1996; Shackleton 1997; Federal Ministry of Economics and Technology 2014).

Firms' participation in the apprenticeship system is voluntary (Winkelmann 1996). However, once decided to participate, firms are subject to the laws of apprenticeship training. The Chambers of Commerce and Industry or Crafts first check whether firms meet the official training standards to train apprentices (Federal Ministry of Education and Research 2013; Federal Ministry of Justice and Consumer Protection 2013a; Bundesausschuss für Berufsbildung 1972; Federal Ministry of Justice and Consumer Protection 2009, 2013b). Granted the official permission to train apprentices, firms and trainees sign a temporary contract for the duration of the apprenticeship including the payment of a reduced wage (Federal Ministry of Education and Research 2013; Federal Ministry of Justice and Consumer Protection 2013a). 
Vocational schools and training firms provide job-related skills, covering approximately 350 occupations (Zimmermann et al. 2013; Troltsch and Walden 2011). At the end of the training, apprentices pass an official job-related exam that is provided by the Chambers of Commerce and Industry or Crafts (Federal Ministry of Education and Research 2013; Federal Ministry of Justice and Consumer Protection 2013a, b). This official exam aims at ensuring a high training quality and should prevent enterprises from teaching firm-specific instead of mainly general knowledge (Beckmann 2002; Zimmermann et al. 2013). According to the investment motive, firms might have an incentive to provide firm-specific knowledge in order to tie graduates to the training firms (Zimmermann et al. 2013).

\section{Methodology and data Methodology}

Based on a dataset of German enterprises from Creditreform, we examine for the first time whether the relative importance of owner-managed SMEs has an effect on firms' apprenticeship activity on the regional level. For this purpose, we regress firms' apprenticeship activity on the share of owner-managed SMEs and numerous control variables on the county level. Since the regional share of owner-managed SMEs is available only for the year 2008, we have to concentrate on the examination of the referring cross section. ${ }^{7}$ Due to persistent considerable differences between the East and the West German apprenticeship system (Troltsch et al. 2009; Troltsch and Walden 2011; Wagner 1998), we focus our estimation on West German regions. ${ }^{8}$ In the German Democratic Republic training was often outsourced from enterprises into central training centres. Moreover, apprenticeships that were not outsourced mainly took place in large enterprises, dominating the East German economic structure Wagner (1998). In the course of German reunification, firms primarily had to adjust to the changing economic structures, neglecting the supply of apprenticeships. In order to ensure a sufficient supply of training positions, especially underrepresented SMEs have been subsidized (Troltsch et al. 2009; Wagner 1998). Whereas in West Germany in 2005 only $10 \%$ of apprentices were trained in publicly funded trainings, the share of apprentices in state-funded trainings in East Germany was about 30\%. Additionally, the German government established publicly funded institutions specialized in training apprentices in East German regions (Grünert et al. 2006). Thus, we exclude East German counties from our analysis. ${ }^{9}$ Concentrating on West German regions is also in line with the existing literature (see e.g. Bellmann and Neubäumer 1999; Franz et al. 2000).

Our empirical approach thus consists of estimating the following regression

$$
\text { Apprenticeship }_{r}=\alpha+\beta \text { Share of Mittelstand firms } r+\gamma \mathrm{X}_{r}+\epsilon_{r}
$$

\footnotetext{
Creditreform collects data about firms over time. However, Creditreform calculated the regional shares of owner-managed SMEs on special request for one year only. Both the regional share of apprentices in all employees and the regional share of Mittelstand firms in all enterprises tend to be relatively stable over time. Thus, firms' apprenticeship activity and the relative importance of owner-managed SMEs vary more widely between regions than over time. However, estimating a cross section bears the risk of endogeneity. For a detailed discussion see "Limitations" section.

${ }^{8}$ According to the territorial boundaries of 31.12.2008, Germany consists of 326 West German counties and 87 East German counties.

${ }^{9}$ We estimate a regression including all German counties as a robustness check in "Results and discussion" section.
} 
with Apprenticeship measuring firms' apprenticeship activity, Share of Mittelstand firms measuring the relative importance of owner-managed SMEs and $X$ being a vector of control variables. The index $r$ denotes the region, an observation comes from, $\epsilon$ is the error term and $\alpha, \beta$ and $\gamma$ are the parameters to be estimated. In our baseline model we estimate the regression using the OLS technique.

However, firms' apprenticeship activity might not only depend on local characteristics, e.g. the local unemployment rate or the regional supply of alternative training opportunities, but also on characteristics of surrounding regions. Moreover, since the pool of potential apprentices in Germany is somewhat limited in the short run, regions compete for potential trainees and might attract them from other regions in order to train a relatively large number of apprentices. Thus, we need to take spatial dependencies between regions into account. However, spatial correlations lead OLS in many cases not to deliver best linear unbiased estimators. Since spatial dependencies usually violate the assumptions of the general linear model, OLS regressions often are expected to be biased (Keilbach 2000; Lerbs and Oberst 2014; Dormann et al. 2007; Gleditsch and Ward 2007; Eckey et al. 2007). Therefore, it is necessary to examine whether our baseline model suffers from serious spatial correlations and to control for the relevant form of spatial interaction, if necessary. Three types of spatial dependencies might occur in linear regressions.

First, the independent variables might exhibit spatial correlations. As an example, firms' apprenticeship activity of the referring region might not only depend on the local supply of potential trainees but perhaps also on the supply of potential apprentices of neighboring regions. In the presence of spatially lagged explanatory variables, a spatial model of the form

$$
Y=\alpha+\theta W X+\beta X+\epsilon, \quad \epsilon \sim N\left(0, \sigma^{2}\right)
$$

should be implemented. $Y$ is the dependent variable, $X$ is a vector of independent variables and $\epsilon$ is a normally distributed error term. $W$ is the contiguity matrix, describing the spatial arrangement of the observed regions. $\theta$ is the vector of coefficients of the spatial lags of the independent variables. The parameters to be estimated are $\alpha, \theta$ and $\beta$.

Second, the dependent variable might be autocorrelated in space. In our research context, firms' apprenticeship activity of a region might be influenced by firms' apprenticeship activities in neighboring regions. In the presence of spatial autocorrelation in the dependent variable, a spatial lag model of the type

$$
Y=\rho W Y+\alpha+\beta X+\epsilon, \quad \epsilon \sim N\left(0, \sigma^{2}\right)
$$

should be used. The parameters to be estimated are $\rho, \alpha$ and $\beta$.

Third, the error term might exhibit spatial autocorrelation. In this case, firms' apprenticeship activity of the referring region might be affected by unobserved characteristics that neighboring regions have in common. In the presence of spatially autocorrelated residuals, a spatial error model of the form

$$
Y=\alpha+\beta X+u, u=\lambda W u+\epsilon, \epsilon \sim N\left(0, \sigma^{2}\right)
$$


should be implemented. $u$ is the spatially dependent and $\epsilon$ the normally distributed error term. The parameters to be estimated are $\alpha, \beta$ and $\lambda$.

However, the three described types of spatial dependencies might also occur in combination. The spatial Durbin model includes a spatially autocorrelated dependent variable together with spatially lagged explanatory variables. The Manski model combines all three forms of spatial correlations Elhorst (2010). In the following, we examine whether and which of the described types of spatial dependence turn out to exist in our data. We thereby follow the specific-to-general approach, starting with the OLS model and then test whether the model needs to be extended with spatial interaction terms Elhorst (2010). In order to test for spatial correlations, we first have to define the contiguity matrix. We use a row standardized contiguity matrix of style queen, including only regions next to the one under consideration, since this type of contiguity matrix is recommended in the literature (see e.g. Dormann et al. (2007), Keilbach (2000), Eckey et al. (2007)). ${ }^{10}$ Using row standardization we control for different numbers of neighbors by equalizing a neighbor's impact on the referring region to the average of all neighbors' influences Keilbach (2000). A detailed analysis in order to find the adequate spatial model to capture the underlying spatial interactions is presented in "Results and discussion" section.

\section{Data}

In line with most of the related literature (see e.g. Franz et al. (2000), Stöger and WinterEbmer (2001)), we use the share of apprentices in all employees subject to social insurance contributions to measure firms' apprenticeship activity. ${ }^{11}$ The referring data on the NUTS-3-level were extracted from the INKAR database of the Federal Institute for Research on Building, Urban Affairs and Spatial Development. Regional apprenticeship activities vary from 2.9 to $8.9 \%$, with a mean of $5.88 \%$. Figure 1 shows the regional quotas of apprentices in 2008 in West Germany. While most central regions turn out to have relatively low apprenticeship activities, the north-western and south-eastern regions mainly show relatively high quotas of apprentices.

In order to measure the regional share of owner-managed SMEs in all firms, we employ a dataset from Creditreform. ${ }^{12}$ Creditreform is the largest German company information service, collecting data on all economically active firms in Germany. The database contains 3,195,389 economically active enterprises located in West Germany at the end of the year $2008 .^{13}$ The Creditreform database allows us to quantify owner-managed SMEs on the regional level. More precisely, it includes information on the legal form, the owners and the chief operating officers of an enterprise. Moreover, the database reports the companies' turnover and the number of employees which are subject to social insurance contributions. Using this information, we can adequately identify

\footnotetext{
${ }^{10}$ Since this is the first paper analyzing the effect of the relative importance of Mittelstand firms on firms' apprenticeship activity on the county level using spatial models, we do not know a priori which type of contiguity matrix is appropriate. Moreover, no objective criteria exist to choose the proper contiguity matrix. Therefore, we decided to employ a simple binary contiguity matrix to ensure not to manipulate the regression results by choosing a complex one.

11 Since employees subject to social insurance contributions include apprentices, a quota between zero and $100 \%$ emerges.

12 Similar data from Creditreform were employed by Audretsch and Keilbach (2004, 2005, 2007, 2008) in order to examine the relationship between knowledge spillovers, entrepreneurship and economic growth in German regions.

13 For a small number of enterprises, no information on the location was available. Thus, we dropped these observations form our sample.
} 


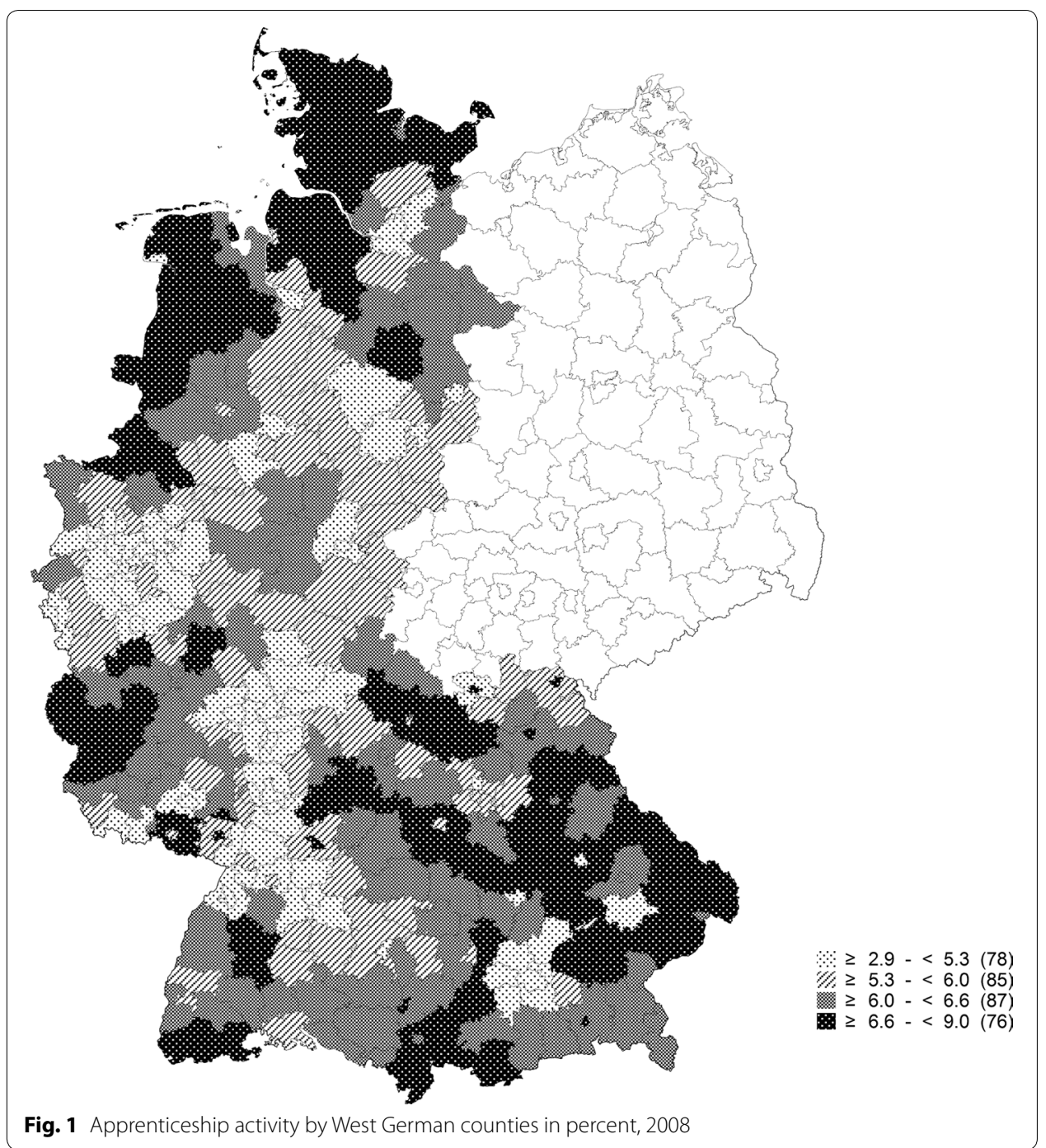

owner-managed SMEs. We consider firms to be owner-managed whenever the chief operating officers of an enterprise also own (at least parts of) the enterprise. However, as the advantage of owner-managed firms tends to diminish with an increasing number of decision makers, we restrict the maximum number of chief operating officers, which are considered to be classified as owner-managed firms, to four. Since we are interested in owner-managed SMEs only, we then apply the definition of SMEs to the identified owner-managed firms. We thereby apply the values used in the definition of the Institut für Mittelstandsforschung Bonn and classify SMEs as firms with less than 500 employees or an annual turnover of less than 50 million Euro. However, according to this definition, only a few owner-managed enterprises do not meet the SME-criteria. Thus, owner-management seems to be the determining criterion of Mittelstand firms. By applying this procedure, we identify 2,602,830 West German firms, respectively $81.46 \%$ of total West German enterprises, as Mittelstand firms. Since the Creditreform database does not report the number of apprentices a firm employs, we cannot estimate the influence of owner-management and firm size on apprenticeship activity on the firm level. Therefore, 
we quantify owner-managed SMEs on a very small regional level in order to analyze the relation between the relative importance of Mittelstand firms and firms' engagement in the apprenticeship system on the regional level. In order to obtain the relative importance of owner-managed SMEs on the NUTS-3-level, we divide the number of ownermanaged SMEs by the total number of firms on the county level. ${ }^{14}$ As the Creditreform database also includes information on employment and turnover, one might think of measuring the regional importance of owner-managed SMEs by the employment or turnover share of Mittelstand firms. However, while for large firms the dataset contains no missing data at all, for many SMEs the employment and turnover data are missing. This is due to the fact that the main business objectives of Creditreform are to provide information about the financial situation of firms and to handle collection orders. In the few cases firms refuse to give information, Creditreform tries to collect information in interviews. Given the huge number of firms in Germany, Creditreform cannot interview all firms for reasons of cost. Since most enquiries address large firms with numerous business connections, Creditreform primarily concentrate on collecting information about large enterprises. While Mittelstand firms are thus classified correctly, there is no adequate information on the employment or turnover share of owner-managed SMEs. Therefore, we have to rely on the share of Mittelstand firms in all economically active firms to measure the regional importance of the Mittelstand. Regional shares of ownermanaged SMEs vary from 58.3 to $91.0 \%$, with a mean of $82.7 \%$. Figure 2 shows the regional quotas of owner-managed SMEs in West Germany. The relative importance of owner-managed SMEs varies more widely across regions than firms' apprenticeship activity. Especially small urban regions seem to have relatively small quotas of ownermanaged SMEs.

Besides the regional share of owner-managed SMEs in all enterprises, various additional factors might have an effect on firms' apprenticeship activity. According to the existing literature, regional unemployment rates might affect firms' engagement in the apprenticeship system (Askilden and Nilsen 2005; Schweri and Wolter 2002; Troltsch and Walden 2011; Blatter et al. 2015; Mühlemann et al. 2007). Referring to the investment motive, firms might train a larger number of apprentices when they expect skilled labour to be scarce in the future. However, whenever firms' expectations about the future are based on the current labour market situation, today's labour market might determine firms' engagement in the apprenticeship system as well (Askilden and Nilsen 2005; Schweri and Wolter 2002). In periods with a tight labour market for skilled workers, firms might also train a larger number of apprentices in order to substitute skilled employees by trainees. Apprentices might take over some tasks in the production process usually handled by semi-skilled or skilled workers (Busemeyer et al. 2012; Backes-Gellner and Mohrenweiser 2010). In order to control for regional labour market tightness, we include the share of the unemployed in the workforce in percent by counties into the regression equation. We expect a negative impact of the unemployment rate on firms' apprenticeship activity. The referring data were also extracted from the aforementioned INKAR database.

${ }^{14}$ The same variable has been used in Berlemann and Jahn (2016). 


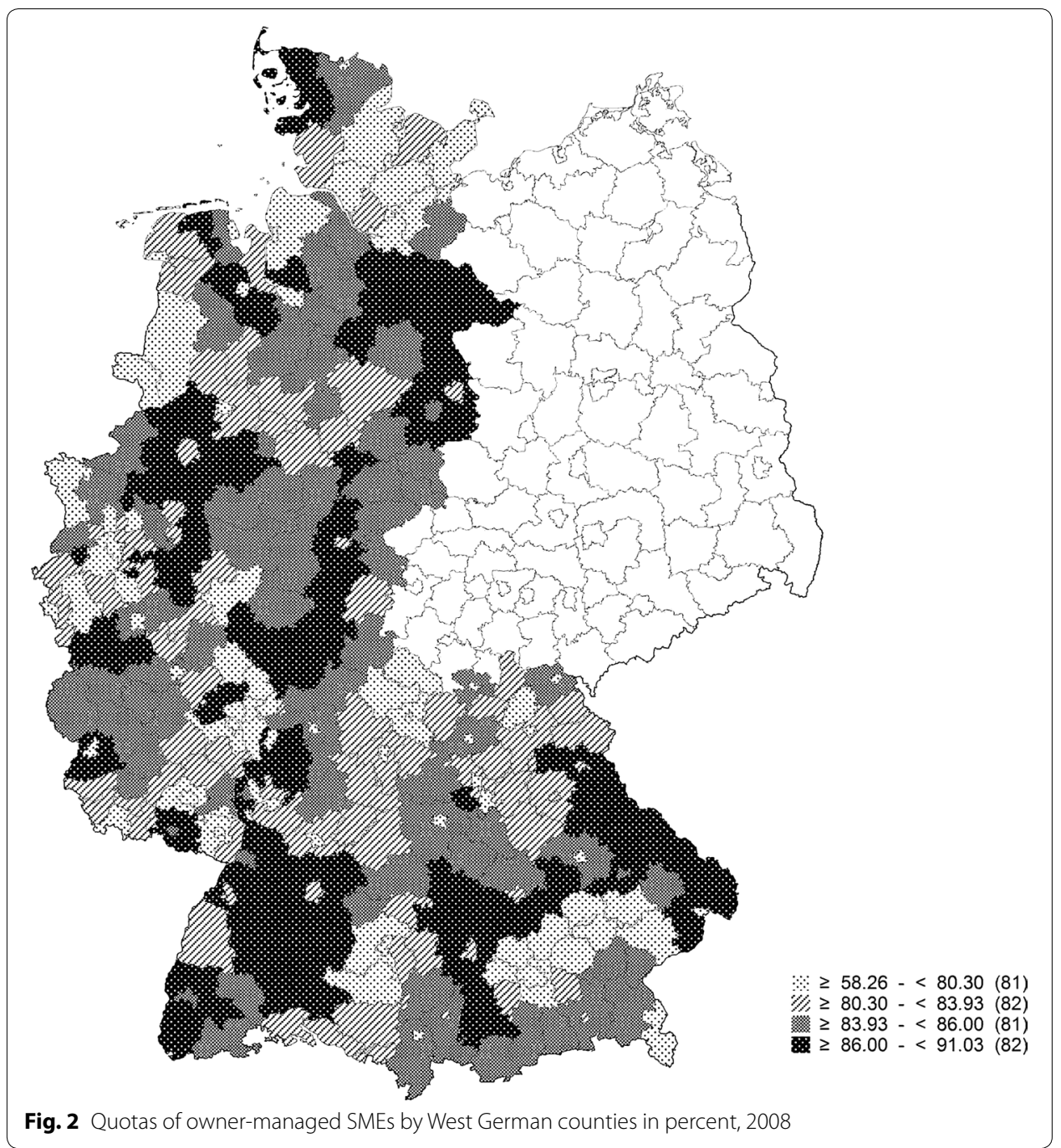

Additionally, the number of potential apprentices per region might influence firms' contribution to the apprenticeship system positively because a relatively large supply of potential trainees might improve the matching between enterprises and candidates (Mühlemann and Wolter 2007; Blatter et al. 2015). In order to measure the regional supply of potential apprentices, we first employ the share of the unemployed younger than 25 years in all unemployed. Second, we use the regional number of graduates and leavers of secondary schools per enterprise as control variable. We thereby take the skill level into account by differentiating between graduates and leavers of secondary schools holding a General Certificate of Secondary Education (Realschulabschluss, medium-skilled) and graduates and leavers who hold a Higher Education Entrance Qualification (Hochschul-, Fachhochschulreife, high-skilled). Data on school graduates and school leavers on the regional level were provided by the Statistical Office of Lower Saxony. In order to calculate the regional supply of potential trainees per enterprise, we use the total number of firms on the NUTS-3-level from the aforementioned Creditreform database. 
However, not all graduates and leavers of secondary schools are interested in dual vocational trainings and instead apply for a place at a university or a university of applied sciences. In order to take this alternative training opportunity into account, we control for the supply of academic training on the NUTS-3-level. Since universities/universities of applied sciences vary considerably in size, we employ the number of academic and artistic personnel. We include the number of academic and artistic personnel at universities/universities of applied sciences per school leaver into the regression equation. Data on the number of academic and artistic personnel at universities/universities of applied sciences on the county level were provided by the German Federal Statistical Office on request. Additionally, we control for the average distance to the next university/university of applied sciences. In order to do so, we calculate the distance between the geometric center of a region without any university/university of applied sciences to the nearest geometric center of a region hosting at least one university/university of applied sciences. The distance to the next university/university of applied sciences in regions where at least one university/university of applied sciences is located in, is zero. As firms compete with universities/universities of applied sciences for graduates of secondary schools, we expect the size of universities/universities of applied sciences to have a negative influence and the distance to have a positive impact on the matching between enterprises and candidates and hence on firms' apprenticeship activity.

Moreover, firms' engagement in the apprenticeship system might vary with the industries, the enterprises are active in (Blatter et al. 2015; Bellmann and Neubäumer 1999; Stöger and Winter-Ebmer 2001; Franz et al. 2000; Beckmann 2002). Hence, we include the share of firms of an industrial sector ${ }^{15}$ in all enterprises per region in percent into the regression equation. Data were extracted from the Creditreform database as well. ${ }^{16}$

Furthermore, firms' contribution to the apprenticeship system might also vary with the occupations, the apprentices are trained in Blatter et al. (2015). Therefore, we also control for the share of employees of different occupational categories ${ }^{17}$ in all employees subject to social insurance contributions by counties in percent. The referring data were provided by the Federal Employment Agency on request. ${ }^{18}$ Since employees subject to social insurance contributions include apprentices, we thus consider the occupations of the employees that might train the apprentices as well as the occupations, apprentices are trained in. However, in most cases, occupations of trainers and trainees should be the same.

Additionally, regional characteristics like the structure of firm size, the share of the working-age population in all inhabitants, population density, GDP per capita, and political attitudes might have an impact on firms' apprenticeship activity on the county level. Political attitudes, measured as the share of valid second votes a political party received in the parliamentary election in 2009, might influence the regional share of Mittelstand firms through political programs as well. In order to take heterogeneity between German

\footnotetext{
${ }^{15}$ Additional file 1: Table S2 shows the referring industrial sector classification (NACE Rev. 2, one digit).

16 However, for roughly $5.7 \%$ of the enterprises in the Creditreform database (183,202 cases) no sector classification is available. The referring firms are summarized in the group 'No sector information'.

17 Due to data availability, we employ the German occupation classification from 1988, shown in Additional file 1 : Table S3.

${ }^{18}$ For a small number of employees no detailed information on the occupation is available. The referring employees are summarized in the group 'No occupational information'.
} 
NUTS-3-regions into account and to work against an omitted variable bias and a possible simultaneity bias, we include regional control variables in our analysis.

For a detailed description and some descriptive statistics of the employed variables see Table 1 and Additional file 1: Table S1.

\section{Results and discussion}

In Table 2 we report the results of our baseline regression approach, explaining firms' apprenticeship activity (Apprenticeship) by the relative importance of owner-managed SMEs (Share of Mittelstand firms) on the county level, estimated using the OLS technique. The first column displays the results of the simple linear regression. The second column shows the estimation results of a model containing all control variables discussed in the previous section. In both models the variable of central interest, the relative importance of Mittelstand firms, turns out to have a significantly positive effect on firms' apprenticeship activity. Several employed control variables also show a significant influence on firms' apprenticeship activity with coefficients having the expected signs.

In order to check the stability of the results of our OLS regressions, we test for possible outliers and multicollinearity. Since regressions without potential outliers lead to similar outcomes as in the analysis including all 326 West German regions, at least with regard to direction and significance of the Share of Mittelstand firms-coefficient, we keep all regions in our sample even within the following empirical analyses. Furthermore, an examination of bivariate correlations and variance inflation factors does not detect any multicollinearity problems. ${ }^{19}$ Additionally, estimation results remain qualitatively unchanged when we include East German regions in our analysis. Results for all German counties are numerically even stronger than estimation results for West German regions. Additional file 1: Table S4 reports the analysis including all German counties.

In order to check whether our dataset exhibits serious spatial interactions, we first use a Moran's I-test (Anselin 1988; Keilbach 2000). This test shows a small but highly significant Moran's I-value of 0.0868 for model (2), identifying positive spatial autocorrelation in the OLS residuals. ${ }^{20}$ This result is likely due to the fact that the OLS baseline regression does not explicitly control for spatial dependencies, and thus they are reflected in the residuals. In order to extend the OLS baseline model by spatial correlations, we estimate a model with spatially lagged explanatory variables Elhorst and Vega (2013). However, the extended model suffers from serious multicollinearity problems and therefore should not be used. ${ }^{21}$ Hence, we apply Lagrange-Multiplier-tests to discover whether a spatial error model or a model with a spatially autocorrelated dependent variable might be adequate to capture the existing spatial interactions Eckey et al. (2006). LagrangeMultiplier-tests detect both models to be potentially appropriate at the $95 \%$-significance level and thus robust Lagrange-Multiplier-tests should be used. The robust tests support the spatial lag model, showing a higher test value for RLMlag (Anselin 2005; Anselin and

\footnotetext{
${ }^{19}$ Since model (2) only serves as a starting point for the following spatial analysis, we do not show the regression results without outliers, the correlation matrix, and the variance inflation factors here. They are instead available from the author on request.

20 Addiional file 1: Figure S1 shows the Moran scatterplot of the OLS residuals.

21 The variance inflation factors of the extended model are available from the author on request.
} 
Table 1 Description of employed variables

\begin{tabular}{|c|c|c|}
\hline Variable & Description & Source \\
\hline Apprenticeship & $\begin{array}{l}\text { Share of apprentices in all employ- } \\
\text { ees subject to social insurance } \\
\text { contributions at place of work } \\
\text { by counties in percent, West } \\
\text { Germany, } 2008^{\mathrm{a}}\end{array}$ & $\begin{array}{l}\text { INKAR database (2010) of the Federal } \\
\text { Institute for Research on Building, } \\
\text { Urban Affairs and Spatial Develop- } \\
\text { ment }\end{array}$ \\
\hline Share of Mittelstand firms & $\begin{array}{l}\text { Number of owner-managed SMEs } \\
\text { relative to all enterprises by } \\
\text { NUTS-3-regions in percent, West } \\
\text { Germany, December 31, } 2008 \text {. } \\
\text { Due to data availability, firms are } \\
\text { localized by headquarters }\end{array}$ & Creditreform database (2008) \\
\hline Unemployment rate & $\begin{array}{l}\text { Share of the unemployed in the } \\
\text { workforce by counties in percent, } \\
\text { West Germany, } 2008\end{array}$ & INKAR database (2010) \\
\hline Unemployed potential trainees & $\begin{array}{l}\text { Share of young people (aged under } \\
25 \text { years) in the unemployed } \\
\text { by counties in percent, West } \\
\text { Germany, } 2008\end{array}$ & INKAR database (2010) \\
\hline $\begin{array}{l}\text { Medium-skilled (high-skilled) } \\
\text { potential trainees }\end{array}$ & $\begin{array}{l}\text { Number of graduates and leavers of } \\
\text { secondary schools in the school } \\
\text { year 2007/08 holding a General } \\
\text { Certificate of Secondary Educa- } \\
\text { tion (Realschulabschluss) (holding } \\
\text { a Higher Education Entrance } \\
\text { Qualification (Hochschul-, Fach- } \\
\text { hochschulreife)) per enterprise by } \\
\text { NUTS-3-regions, West Germany, } \\
2008\end{array}$ & $\begin{array}{l}\text { Statistical Office of Lower Saxony } \\
(2010), \text { Creditreform database } \\
(2008)^{b}\end{array}$ \\
\hline Size of universities & $\begin{array}{l}\text { Number of academic and artistic } \\
\text { personnel at universities and } \\
\text { universities of applied sci- } \\
\text { ences per graduate or leaver of } \\
\text { secondary school' in the school } \\
\text { year } 2007 / 2008 \text { by counties, } \\
\text { West Germany, 2008. In order to } \\
\text { deal adequately with academic } \\
\text { personnel working part-time, we } \\
\text { report full-time equivalent values }\end{array}$ & German Federal Statistical Office ${ }^{b}$ \\
\hline Distance to universities & $\begin{array}{l}\text { Distance to the nearest university/ } \\
\text { university of applied sciences in } \\
\text { meter }\end{array}$ & Own calculation \\
\hline Sectors & $\begin{array}{l}\text { Share of enterprises of the referring } \\
\text { industrial sectord in all enterprises } \\
\text { by NUTS-3-regions in percent, } \\
\text { West Germany, 2008. Whenever } \\
\text { a firm is active in various sectors, } \\
\text { we report the industrial sector } \\
\text { in which a company generates } \\
\text { its largest turnover. The share of } \\
\text { enterprises without sector infor- } \\
\text { mation is reported as 'No sector } \\
\text { information' }\end{array}$ & Creditreform database $(2008)^{\mathrm{b}}$ \\
\hline
\end{tabular}


Table 1 continued

\begin{tabular}{|c|c|c|}
\hline Variable & Description & Source \\
\hline Occupations & $\begin{array}{l}\text { Share of employees of the refer- } \\
\text { ring occupational categorye in } \\
\text { all employees subject to social } \\
\text { insurance contributions at place } \\
\text { of work by counties in percent, } \\
\text { West Germany, June 30, 2008. } \\
\text { Employees without informa- } \\
\text { tion about their occupations, } \\
\text { non-agricultural family workers, } \\
\text { labourers with occupation still to } \\
\text { be specified and labourers not } \\
\text { further specified are summarized } \\
\text { in the group 'No occupational } \\
\text { information' }\end{array}$ & Federal Employment Agency ${ }^{b}$ \\
\hline Small (large) firms & $\begin{array}{l}\text { Share of companies with minimum } \\
\text { ten and maximum } 49 \text { (with mini- } \\
\text { mum 50) employees subject to } \\
\text { social insurance contributions in } \\
\text { all enterprises by NUTS-3-regions } \\
\text { in percent, West Germany, 2008. A } \\
\text { further differentiation according } \\
\text { to the number of employees is } \\
\text { not feasible due to secrecy in } \\
\text { some regions }\end{array}$ & $\begin{array}{l}\text { Federal Statistical Office and the Sta- } \\
\text { tistical Offices of the Länder (2016) }\end{array}$ \\
\hline Population density & $\begin{array}{l}\text { Population per square kilometer by } \\
\text { NUTS-3-regions, West Germany, } \\
2008\end{array}$ & $\begin{array}{l}\text { Federal Institute for Research on } \\
\text { Building, Urban Affairs and Spatial } \\
\text { Development }\end{array}$ \\
\hline Working-age population & $\begin{array}{l}\text { Share of population aged } 15 \text { to } \\
65 \text { in all inhabitants by counties, } \\
\text { West Germany, } 2008\end{array}$ & $\begin{array}{l}\text { Statistical Office of Lower Saxony } \\
\text { (2010) }\end{array}$ \\
\hline GDP per capita & $\begin{array}{l}\text { Gross Domestic Product (GDP) per } \\
\text { capita at current prices ( } € \text {, thou- } \\
\text { sands) by NUTS-3-regions, West } \\
\text { Germany, } 2008\end{array}$ & $\begin{array}{l}\text { Statistical Offices of the Länder } \\
\text { (2010) }\end{array}$ \\
\hline CDU/CSU/ FDP (other parties) & $\begin{array}{l}\text { Share of valid second votes CDU/ } \\
\text { CSU and FDP (other parties) } \\
\text { received in the parliamentary } \\
\text { elections in } 2009\end{array}$ & $\begin{array}{l}\text { Federal Returning Officer (Bun- } \\
\text { deswahlleiter) }\end{array}$ \\
\hline \multicolumn{3}{|c|}{$\begin{array}{l}\text { The value for Flensburg was missing ( } 0.0) \text { in the original data. In consultation with the data provider, we added the } \\
\text { missing value }(7.2)\end{array}$} \\
\hline \multicolumn{3}{|l|}{ b Special analysis on request } \\
\hline \multicolumn{3}{|c|}{ c In Bavaria including commercial colleges } \\
\hline \multicolumn{3}{|c|}{ d Industrial sectors according to NACE Rev. 2, one-digit-level (see Additional file 1: Table S2) } \\
\hline \multicolumn{3}{|c|}{$\begin{array}{l}\text { e Occupational categories according to the German occupational classification from } 1988 \text { (see Additional file 1: Table S3). } \\
\text { Shares of occupational categories and 'No occupational information' do not add to } 100 \% \text { due to anonymization }\end{array}$} \\
\hline \multicolumn{3}{|c|}{$\begin{array}{l}\text { f Other parties are defined as all parties taking part in the parliamentary elections in } 2009 \text { except CDU/CSU, FDP, SPD, and } \\
\text { Die Grünen }\end{array}$} \\
\hline
\end{tabular}

Florax 1995; Elhorst et al. 2010). ${ }^{22}$ Therefore, we estimate a model with spatial interaction in the dependent variable using the Maximum-Likelihood-technique. However, this spatial lag model might suffer from omitted variable bias since it does not account for spatially lagged independent variables. In this case, the spatial Durbin model would be appropriate, extending the spatial lag model by spatial correlations in the explanatory variables (see e.g. Elhorst et al. 2010). Thus, we estimate a spatial Durbin model and 
Table 2 OLS

\begin{tabular}{lll}
\hline Dependent variable: Apprenticeship & & \\
\hline & $(\mathbf{1})$ & $(\mathbf{2})$ \\
\hline Share of Mittelstand firms & $0.0496^{* * *}$ & $0.0251^{* *}$ \\
Unemployment rate & & $-0.0414^{*}$ \\
Unemployed potential trainees & & $0.0790^{* * *}$ \\
Medium-skilled potential trainees & & -2.4162 \\
High-skilled potential trainees & & -0.0753 \\
Size of universities & & $-0.3006^{*}$ \\
Distance to universities & & $0.0049^{*}$ \\
Small firms & & $0.2290^{* * *}$ \\
Large firms & & -0.0239 \\
Working-age population & & 0.0331 \\
Population density & & 0.0001 \\
GDP per capita & & -0.0084 \\
CDU/CSU/FDP & & $0.0254^{* * *}$ \\
Other parties & & $0.0579^{* * *}$ \\
Sectors & 326 & $\times$ \\
Occupations & 0.07 & $\times$ \\
$N$ & $25.4^{* * *}$ & 326 \\
adj $R^{2}$ & & 0.698 \\
F-value & & $13.7^{* * *}$ \\
\hline
\end{tabular}

${ }^{* * *} p<0.01,{ }^{* *} p<0.05,{ }^{*} p<0.1$

contrast it with the spatial lag model using a Likelihood-Ratio-test. The LikelihoodRatio-test, especially adapted to spatial models, detects the spatial Durbin model to better describe the underlying data (Anselin 2003; Elhorst 2010; Angulo and Mur 2011). Therefore, we reject the spatial lag model in favor of the spatial Durbin model. As a major strength of the model, the spatial Durbin model leads to unbiased coefficient estimates even when the data generating process follows another spatial regression equation LeSage and Pace (2009), unless the true data generating process is of the Manski type Elhorst (2010). ${ }^{23}$ In order to check whether the spatial Durbin model or the Manski model is appropriate to capture the existing spatial dependencies, we estimate a Manski model. The only difference between the spatial Durbin model and the Manski model is the spatially lagged error term. Since $\lambda$ turns out to be highly significant, we reject the spatial Durbin model in favor of the Manski model Elhorst and Vega (2013). At the end, the Manski model qualifies as the adequate spatial model to capture the underlying spatial interactions. ${ }^{24}$

The results of the Manski model are shown in Table 3. The Manski model fits the data very well, showing a Nagelkerke pseudo R squared of 0.8386. $\rho$ turns out to be highly significant, indicating a considerable spatial autocorrelation of firms' apprenticeship activity.

\footnotetext{
${ }^{23}$ Although the Kelejian-Prucha model nests the spatial lag model as well, we refrain from estimating a Kelejian-Prucha model because it produces biased estimates when the true data generating process follows another spatial regression specification (LeSage and Pace 2009; Elhorst 2010).

${ }^{24}$ Results of the spatial lag model, the spatial Durbin model and the Likelihood-Ratio-test are available from the author on request.
} 
Table 3 Manski model

\begin{tabular}{llcc}
\hline & Direct effects & Indirect effects & Total effects \\
\hline Share of Mittelstand firms & $0.0218^{*}$ & $-0.0849^{*}$ & -0.0631 \\
Unemployment rate & 0.0273 & 0.0280 & 0.0553 \\
Unemployed potential trainees & $0.0580^{* * *}$ & $0.2556^{* * *}$ & $0.3136^{* * *}$ \\
Medium-skilled potential trainees & 0.6358 & -8.1262 & -7.4904 \\
High-skilled potential trainees & -0.6437 & 1.0097 & 0.3660 \\
Size of universities & -0.0666 & -0.5825 & -0.6491 \\
Distance to universities & $0.0066^{* * *}$ & 0.0028 & 0.0094 \\
Small firms & $0.0916^{*}$ & -0.0758 & 0.0158 \\
Large firms & 0.0040 & 0.7407 & 0.7447 \\
Working-age population & 0.0103 & 0.1370 & 0.1474 \\
Population density & 0.0000 & 0.0002 & 0.0002 \\
GDP per capita & $-0.0162^{* *}$ & 0.0132 & -0.0030 \\
CDU/CSU/FDP & $0.0306^{* *}$ & -0.0389 & -0.0083 \\
Other parties & 0.0309 & -0.0799 & -0.0489 \\
$N$ & 326 & & \\
Nagelkerke & 0.8386 & & \\
$\rho$ & $0.5222(0.0000)$ & & \\
$\lambda$ & $-0.7407(0.0000)$ & & \\
\hline
\end{tabular}

Industrial sectors and occupations are further controls not reported in this table. Additional file 1: Table S6 reports the results of the Manski model including sectors and occupations

*** $p<0.01,{ }^{* *} p<0.05,{ }^{*} p<0.1$.

According to LeSage and Pace (2009), Gleditsch and Ward (2007) and Elhorst (2014), the regression coefficients of models containing a spatially lagged dependent variable, like the Manski model, should not be interpreted since they ignore feedback effects. Feedback effects are a consequence of the spatial autocorrelation of the explained variable. They measure impacts on the explained variable of a region that pass on to neighboring regions and then back to the referring region (Elhorst 2014; Gleditsch and Ward 2007; LeSage and Fischer 2008). We therefore calculate direct, indirect and total effects of the independent variables, taking feedback effects into account. Direct effects measure the impact of a particular independent variable on the dependent variable of the same region. Indirect effects, also named spillover effects, describe the influence of a single explanatory variable on the explained variables of all other regions. Using an alternative interpretation, indirect effects measure the change in the dependent variable of the referring region due to an increase in a particular explanatory variable in all other regions. Total effects are the sum of the direct and indirect impacts (LeSage and Pace 2009; Elhorst et al. 2010; LeSage and Fischer 2008). ${ }^{25}$ Total effects report the overall impact of a single explanatory variable of the referred region, within and across regions. Changing perspectives, total effects measure the overall impact on the explained

25 The Manski model does not impose any restictions on the magnitude of the direct and indirect effects. Therefore, the ratio between the direct and indirect effects may differ across explanatory variables. This flexibility makes the Manski model an attractive spatial model (Elhorst 2014). 
variable of a particular region due to nationwide changes in a single independent variable. Total effects might therefore be interpreted as national impacts, taking effects within and across regions into account.

The variable of central interest, the relative importance of Mittelstand firms, turns out to positively influence firms' apprenticeship activity. The direct effect is significant on the 90\%-confidence level. An increase in the regional share of owner-managed SMEs significantly raises firms' apprenticeship activity in the same region. However, the indirect effect is significantly negative, indicating apprenticeship activities in surrounding regions to fall when the share of Mittelstand firms in the referring region raises. An increasing relative importance of owner-managed SMEs in the referring region might potentially attract apprentices from other regions. Using the alternative interpretation, an increase in the quotas of owner-managed SMEs in surrounding regions has a significantly negative influence on the apprenticeship activity of the referring region. The indirect effect is larger than the direct effect since spillover effects are cumulated over all regions. The indirect effect falling on any single region however is likely much smaller than the direct effect (LeSage and Pace 2009; LeSage and Fischer 2008). The negative indirect effect cancels out the significantly positive direct impact, leading to a non-significant total effect. Hence, a relatively large share of Mittelstand firms is a relative regional advantage that disappears when the relative importance of owner-managed SMEs in surrounding regions also increases. This effect is quite plausible as all regions tend to compete for the same pool of potential apprentices.

We neither find a significant direct nor indirect impact of the regional unemployment rate on firms' apprenticeship activity. The total effect turns out to be insignificant as well. Possibly, firms' expectations about the future supply of skilled labour as a reason to train apprentices according to the investment motive is not only based on the current labour market situation. The supply of potential trainees currently unemployed turns out to influence firms' apprenticeship activity significantly positive, both within and across regions. The education level of potential trainees as well as the quantity of the regional supply of academic training tend to have no significant impact. The accessibility of universities/universities of applied sciences however seems to play a role. The greater the distance to the next university/university of applied sciences, the higher the regional share of apprentices in all employees.

\section{Limitations}

Estimating a cross section bears the risk of endogeneity. First, endogeneity might influence the results in the form of a simultaneity bias. Although we control for a large number of variables, we cannot completely rule out that unobserved regional characteristics might affect both, the regional share of Mittelstand firms and firms' apprenticeship activities. In order to address this problem, we employ a cluster analysis. Thereby, we first calculate the Euclidean distances between regions based on all employed control variables. In the second step, Euclidean distances are used to cluster regions into different groups. It turns out that German counties are relatively comparable. Only a few regions are identified as substantially different from the others. Thus, one main cluster of homogenous regions emerges. Reestimating the baseline model focusing on homogenous regions only, confirms the results from "Results and discussion" section. In order 
to build the cluster analysis on a larger number of regions, we conduct a further cluster analysis based on all German counties. We again find a significantly positive effect of the relative importance of Mittelstand firms on firms' apprenticeship activities. The effect found from the cluster analyses is numerically even stronger than the effect from the baseline model. A spatial analysis based on homogenous regions is infeasible since regions are not necessarily adjacent.

The second aspect of endogeneity is reverse causality. Reverse causality however does not seem to play a role in our empirical analysis. There is neither a credible theoretical argument for reverse causality nor empirical evidence pointing in this direction. Since no clear instrument variable is available for owner-managed SMEs, we have little possibilities to formally control for reverse causality.

\section{Summary and conclusion}

Since Mittelstand Firms are attributed to play an important role in the German economy, German policy makers has established numerous political programs to support Mittelstand Firms on the regional as well as on the national level. Politicians often emphasize the important role of owner-managed SMEs by stating that Mittelstand firms excessively engage in the German apprenticeship system. However, there has been almost no empirical evidence on the question whether Mittelstand firms are in fact excessively active in training apprentices yet. Based on a dataset of German enterprises, we examine for the first time the relationship between the relative importance of owner-managed SMEs and firms' apprenticeship activity on the regional level. Taking numerous control variables and various types of spatial dependencies between regions into account, we find a significantly positive effect of the relative importance of owner-managed SMEs on apprenticeship activity on the county level. Thus, regions with a higher relative importance of Mittelstand firms seems to be overly successful in attracting trainees and especially train a larger number of apprentices relative to all employees than other regions. However, since the pool of potential apprentices in Germany is somewhat limited in the short run, German counties compete for potential trainees. This competition leads the relative regional advantage of a higher relative importance of Mittelstand firms to disappear when other regions show a higher relative importance of owner-managed SMEs as well.

Although we have to rely on cross sectional data due to data availability, impeding a clear causal identification strategy, we dare some policy implications from our empirical analysis. Political promotion of the local Mittelstand, increasing the regional share of Mittelstand firms in all enterprises, seems to be a reasonable instrument in order to raise firms' apprenticeship activity in a particular region. However, policy makers should be aware that this turns out to come at the price that a relatively large share of owner-managed SMEs in a particular region attracts potential trainees from surrounding regions, leading firms' apprenticeship activity to decrease there. This negative spillover effect tends to outweigh the positive impact of the relative importance of Mittelstand firms on firms' apprenticeship activity on a higher regional level. Countries aiming at adopting the German Mittelstand model should take these mechanisms into account.

While we analyze the link between Mittelstand firms and firms' apprenticeship activity on the regional and the national level, we cannot be sure that Mittelstand firms account for the larger regional share of apprentices. Whereas it seems to be natural to attribute 
the higher regional apprenticeship activities to local Mittelstand firms, it might also be the case that non-owner-managed or large firms train a larger number of apprentices in the presence of a high share of regionally competing Mittelstand firms. Although this analysis is infeasible with the dataset at hand and thus has to be left open for future research, the result is less important for policy implications to be drawn on the regional and national level.

\section{Additional file}

Additional file 1. Additional tables and figure.

\section{Authors' contributions}

VJ is solely responsible for the content of the paper. The author read and approved the final manuscript.

\section{Acknowledgements}

The author acknowledges helpful comments and recommendations by Michael Berlemann, Max Steinhardt, and Cain Polidano, the participants of the Annual Conference of the Verein für Socialpolitik 2017 in Vienna, Austria, the 3rd Workshop on Spatial Dimensions of the Labour Market 2017 at the Centre for European Economic Research (ZEW) in Mannheim, Germany, the Conference on Economic, Technological and Societal Impacts of Entrepreneurial Ecosystems 2017 in Augsburg, Germany, the Brown Bag Seminar at the Melbourne Institute of Applied Economic and Social Research at the University of Melbourne 2016 in Melbourne, Australia, the IAB-Colloquium at the Institute for Employment Research (IAB) 2016 in Nuremberg, Germany, the Brown Bag Seminar at the TU Dresden 2015 in Dresden, Germany, the Scottish Economic Society Annual Conference 2015 in Perth, Scotland, and the Brown Bag Seminar at the Helmut Schmidt University 2014 in Hamburg, Germany. The author also thanks two anonymous reviewers for valuable suggestions improving the quality of the paper. Previous versions of this paper are available online as a working paper in Helmut Schmidt University Working Paper Series, No. 158 and as a conference paper (https://www.econstor.eu/bitstream/10419 /168260/1/NfS-2017-pid-3482.pdf)

Competing interests

The author declares that she has no competing interests.

\section{Availability of data and materials}

Most of the data used are publicly available from INKAR database, Statistical Offices and the Federal Institute for Research on Building, Urban Affairs and Spatial Development. However, some variables employed in the regression analysis are not publicly available. They are instead available from the corresponding author on reasonable request. Table 1 in the paper mentions the source of every single variable used.

\section{Consent for publication}

Not applicable.

Ethics approval and consent to participate

Not applicable.

Funding

Not applicable.The author did not receive any funding for this research paper.

\section{Publisher's Note}

Springer Nature remains neutral with regard to jurisdictional claims in published maps and institutional affiliations.

Received: 12 January 2018 Accepted: 18 June 2018

Published online: 16 July 2018

\section{References}

Acemoglu D, Pischke J-S (1999) Beyond becker: training in imperfect labour markets. Econ J 109(453):F112-F142

Angulo AM, Mur J (2011) The likelihood ratio test of common factors under non-ideal conditions. Invest Reg 21:37-52

Anselin L (1988) Spatial econometrics methods and models. Kluwer Acad Publ, Dordrecht

Anselin L (2003) An introduction to spatial regression analysis in $R$

Anselin L (2005) Exploring spatial data with GeoDaTM: a workbook

Anselin L, Florax RJGM (1995) Small sample properties of tests for spatial dependence in regression models: some further results. In: Anselin L, Florax R (eds) New directions in spatial econometrics. Springer, Berlin, pp 21-74 
Askilden JE, Nilsen ØA (2005) Apprentices and young workers: a study of the norwegian youth labour market. Scott J Polit Econ 52(1):1-17

Audretsch DB, Lehmann E (2016) The seven secrets of Germany. Oxford University Press, Economic resilience in an era of global turbulence, New York

Audretsch DB, Keilbach M (2004) Entrepreneurship and regional growth: an evolutionary interpretation. J Evol Econ 14(5):605-616

Audretsch DB, Keilbach M (2005) Entrepreneurship capital and regional growth. Ann Reg Sci 39(3):457-469

Audretsch DB, Keilbach M (2007) The theory of knowledge spillover entrepreneurship. J Manag Stud 44(7):1242-1254

Audretsch DB, Keilbach M (2008) Resolving the knowledge paradox: knowledge-spillover entrepreneurship and economic growth. Res Policy 37(10):1697-1705

Backes-Gellner U, Mohrenweiser J (2010) Apprenticeship training: for investment or substitution? Int J Manpower 31(5):545-562

Bavarian Ministry of Economic Affairs and Media, Energy and Technology (2009) Wegweiser zu Fördermöglichkeiten für Existenzgründer und Mittelstand in Bayern. Bavarian Ministry of Economic Affairs and Media, Energy and Technology, Munich

Becker GS (1993) Human capital: a theoretical and empirical analysis, with special reference to education, 3rd edn. The Univ. of Chicago Press, Chicago

Beckmann M (2002) Firm-sponsored apprenticeship training in Germany: empirical evidence from establishment data. LABOUR 16(2):287-310

Bellmann L, Neubäumer R (1999) Ausbildungsintensität und Ausbildungsbeteiligung von Betrieben: theoretische Erklärungen und empirische Ergebnisse auf der Basis des IAB-Betriebspanels 1997. In: Beer D, Frick B, Neubäumer R, Sesselmeier W (eds) Die wirtschaftlichen folgen von aus- und weiterbildung. Rainer Hampp Verlag, München und Mering, pp 9-42

Berghoff H (2006) The end of family business? the Mittelstand and German capitalism in transition, 1949-2000. Bus Hist $\operatorname{Rev} 80(2): 263-295$

Berlemann M, Jahn V (2016) Regional importance of Mittelstand Firms and innovation performance. Reg Stud 50(11):1819-1833

Blackstone B, Fuhrmans V (2011) The engines of growth. Wall Street J, 27 June 2011

Blatter M, Muehlemann S, Schenker S, Wolter SC (2015) Hiring costs for skilled workers and the supply of firm-provided training. Oxford Econ Papers 68(1):238-257

Bundesausschuss für Berufsbildung (1972) Empfehlung über die Eignung der Ausbildungsstätten

Busemeyer MR, Neubäumer R, Pfeifer H, Wenzelmann F (2012) The transformation of the German vocational training regime: evidence from firms' training behaviour. Ind Relat J 43(6):572-591

Chrisman JJ, Chua JH, Litz RA (2004) Comparing the agency costs of family and non-family firms: conceptual issues and exploratory evidence. Entrepreneurship Theory Pract 28(4):335-354

Chu W (2009) The influence of family ownership on SME performance: evidence from public firms in Taiwan. Small Bus Econ 33(3):353-373

Dormann CF, McPherson JM, Araújo MB, Bivand R, Bolliger J, Carl G, Davies RG, Hirzel A, Jetz W, Kissling WD, Kühn I, Ohlemüller R, Peres-Neto PR, Reineking B, Schröder B, Schurr FM, Wilson R (2007) Methods to account for spatial autocorrelation in the analysis of species distributional data: a review. Ecography 30(5):609-628

Eckey H-F, Kosfeld R, Türck M (2006) Räumliche Ökonometrie. Wirtschaftswissenschaftliches Studium (WiSt) 35(10):548-554

Eckey H-F, Kosfeld R, Türck M (2007) Regionale Entwicklung mit und ohne räumliche Spillover-Effekte. Jahrbuch für Regionalwissenschaft 27(1):23-42

Elhorst JP (2010) Applied spatial econometrics: raising the bar. Spatial Econ Anal 5(1):9-28

Elhorst JP (2014) Spatial econometrics. From cross-sectional data to spatial panels. Springer, Heidelberg

Elhorst JP, Halleck V (2013) On spatial econometric models, spillover effects, and W. In: ERSA conference papers, No. ersa13p222

Elhorst JP, de Haan J, Seldadyo H (2010) Geography and governance: does space matter? Papers Reg Sci 89(3):625-640

Fama EF, Jensen MC (1983) Separation of ownership and control. J Law Econ 26(2):301-325

Fear J (2014) The secret behind Germany's thriving 'Mittelstand' businesses is all in the mindset. Conversation, 28 April 2014

Federal Chancellor Angela Merkel (2009) Mittelstand-Rückgrat der Sozialen Marktwirtschaft

Federal Ministry of Economic Affairs and Energy (2014) Central innovation programme for SMEs. Boosting innovation

Federal Ministry of Economic Affairs and Energy (2015) Aktionsprogramm Zukunft Mittelstand. Federal Ministry of Economic Affairs and Energy, Berlin

Federal Ministry of Economics and Technology (2009) Mittelstand: Leistung durch Vielfalt

Federal Ministry of Economics and Technology (2013) German Mittelstand: engine of the German economy: facts and figures about small and medium-sized German Firms

Federal Ministry of Economics and Technology (2014) A successful SME policy for growth in Europe

Federal Ministry of Education and Research (2013) Ausbildung und Beruf. Rechte und Pflichten während der Berufsausbildung

Federal Ministry of Justice and Consumer Protection (2009) Ausbilder-Eignungsverordnung (AusbEignV)

Federal Ministry of Justice and Consumer Protection (2013a) Berufsbildungsgesetz (BBiG)

Federal Ministry of Justice and Consumer Protection (2013b) Gesetz zur Ordnung des Handwerks. Handwerksordnung, HwO

Franz W, Steiner V, Zimmermann V (2000) Die betriebliche Ausbildungsbereitschaft im technologischen und demographischen Wandel. Nomos-Verl.-Ges, Baden

Girotra K, Netessine S (2013) Extreme focus and the success of Germany's Mittelstand. Harvard Bus Rev, 12 February 2013

Gleditsch KS, Ward MD (2007) An introduction to spatial regression models in the social sciences. Duke University, Duke 
Grünert H, Lutz B, Wiekert I (2006) Zukunftsperspektiven der Berufsausbildung in den neuen Ländern und die Rolle der Bildungsträger. Zentrum für Sozialforschung Halle e.V. an der Martin-Luther-Universität Halle-Wittenberg, Halle Hamel W (2006) Personalwirtschaft. In: Pfohl H-C, Arnold U (eds) Betriebswirtschaftslehre der Mittel- und Kleinbetriebe. E. Schmidt, Berlin, pp 233-260

Institut für Mittelstandsforschung Bonn (2013) Der deutsche Mittelstand: Ein Konglomerat verschiedenartiger Unternehmen. In: IfM Standpunkt, p. 1

Keilbach MC (2000) Spatial knowledge spillovers and the dynamics of agglomeration and regional growth. Physica-Verl, Heidelberg

Kets de Vries MFR (1993) The dynamics of family controlled firms: the good and the bad news. Org Dyn 21(3):59-71

Kirchfeld A, Randow J (2010) Germany's Mittelstand still thrives. Bloomberg Businessweek, 30 September 2010

Krämer W (2003) Mittelstandsökonomik: Grundzüge einer umfassenden Analyse kleiner und mittlerer Unternehmen. Vahlen, München

Lerbs OW, Oberst CA (2014) Explaining the spatial variation in homeownership rates: results for German regions. Reg Stud 48(5):844-865

LeSage J, Fischer MM (2008) Spatial growth regressions: model specification, estimation and interpretation. Spatial Econ Anal 3(3):275-304

LeSage J, Fischer MM (2009) Introduction to spatial econometrics. CRC Press, Boca Raton

Ministry of Economic Affairs, Energy and Industry of the State of North Rhine-Westphalia (2014) Daten und Fakten

Mühlemann S, Wolter SC (2007) Regional effects on employer-provided training: evidence from apprenticeship training in Switzerland. J Labour Market Res 40(2/3):135-147

Mühlemann S, Schweri J, Winkelmann R, Wolter SC (2007) An empirical analysis of the decision to train apprentices. LABOUR 21(3):419-441

Ryan P (2001) The school-to-work transition: a cross-national perspective. J Econ Literat 39(1):34-92

Schweri J, Wolter SC (2002) The cost and benefit of apprenticeship training: the swiss case. Konjunkturpolitik 48(3-4):347-367

Shackleton JR (1997) Training in Germany: a view from abroad. Educ Train 39(8):303-308

Stöger K, Winter-Ebmer R (2001) Lehrlingsausbildung in Österreich: Welche Betrieben bilden Lehrlinge aus? In: Working paper, Department of Economics, Johannes Kepler University of Linz, vol. 0110

Troltsch K, Walden G (2011) Apprenticeship training in Germany-still a future-oriented model for recruiting skilled workers? J Vocat Educ Train 63(3):305-322

Troltsch K, Walden G, Zopf S (2009) Im Osten nichts Neues? BIBB Report. Forschungs-und Arbeitsergebnisse aus dem Bundesinstitut für Berufsbildung, No. 12/09

UKTrade and Invest, GE Capital, Nabarro, and GSK Stockmann und Kollegen (2014) Meet the Mittelstand, How German Mid-size Companies Went Global

Wagner J (1997) Firm size and job quality: a survey of the evidence from Germany? Small Bus Econ 9(5):411-425

Wagner K (1998) The German apprenticeship system after unification. Social science research center berlin discussion paper series, FS I 98-301

Winkelmann R (1996) Employment prospects and skill aquisition of apprenticeship-trained workers in Germany. Ind Labor Rel Rev 49(4):658-672

Zimmermann KF, Biavaschi C, Eichhorst W, Giulietti C, Kendzia MJ, Muravyev A, Pieters J, Rodríguez-Planas N, Schmidl R (2013) Youth unemployment and vocational training. Found Trends Microecon 9(1-2):1-157

\section{Submit your manuscript to a SpringerOpen ${ }^{\circ}$ journal and benefit from:}

- Convenient online submission

- Rigorous peer review

- Open access: articles freely available online

- High visibility within the field

- Retaining the copyright to your article

Submit your next manuscript at $\boldsymbol{\Delta}$ springeropen.com 